\section{Biostimulant Influences on Turfgrass Microbial Communities and Creeping Bentgrass Putting Green Quality}

\author{
S.R. Mueller \\ Department of Biological Sciences, University of Cincinnati, P.O. Box 210006, \\ Cincinnati, OH 45221-0006
}

\author{
W.R. Kussow ${ }^{1}$ \\ Department of Soil Science, University of Wisconsin-Madison, 1525 \\ Observatory Drive, Madison, WI 53706
}

Additional index words. biostimulant, microbial community, visual quality, putting green, creeping bentgrass

\begin{abstract}
Immature sand matrix golf putting greens are considered to be inhospitable environments for microorganisms as compared to native soils. Subsequently, turfgrass quality may suffer in the absence of beneficial microbe-plant interactions. The turfgrass industry has responded by marketing a wide array of biostimulant products that claim to improve putting green quality through influences on soil microbial activity. A field study was conducted to determine what influences five commercial biostimulants have on the root-zone microbial community and creeping bentgrass (Agrostis stolonifera L.) quality. A three year old U.S. Golf Association (USGA) specification sand-based putting green (e.g., $80 \%$ sand: $20 \%$ peat humus by volume) was the test site. Commercially available biostimulants and fertilizer were applied biweekly from May until August 2000. The soil microbial community was characterized using soil enzymes and substrate utilization profiles. Turfgrass quality was determined visually by evaluating color, percentage of localized dry spot (LDS), and overall uniformity. Nutrient uptake levels were monitored to ascertain if increases in quality related to plant health. Visual quality of the putting green was significantly improved $(p<0.05)$ by the commercial biostimulants. The positive response to biostimulants was not of a nutritional origin. The biostimulants did not effectively alter the putting green microbial community in terms of enzyme activity or substrate utilization. However, a seasonal decline was detected in cellulase activity, which prevailed over any treatment effect, suggesting the root-zone microbial community responded to summer decline of bentgrass roots and concomitant decreases in quantities of root exudates. Visual improvements in putting green quality during the period of summer stress were primarily associated with the incidence of LDS. Visual LDS ratings were significantly reduced (less LDS) by applications of the biostimulants on each observation date $(p<0.05)$ and over the entire course of the experiment $(p<0.10)$. Surfactant properties of the biostimulants therefore appeared to play a major role in the improvements in putting green quality. This does not negate the fact that the seaweed extracts and humic acids in the biostimulants may have improved the heat and moisture stress tolerance of the bentgrass once the LDS formed.
\end{abstract}

The preferred construction of golf putting greens is a 30 -cm layer of properly graded sand (root zone) over a subdrainage system [U.S. GolfAssociation(USGA), 1993]. This ensures rapid water infiltration and drainage, provides resistance to compaction and facilitates maintenance of a smooth playing surface. The sand may or may not be amended with up to $20 \%$ by volume of organic material to improve moisture and nutrient retention (McCoy, 1992). A common organic amendment is sphagnum peat moss, which is considered a low quality carbon resource for soil microbes. Whether amended or not, soil aggregation does not occur in sand-based putting greens as in a native soil system, decreasing microenvironments for microbes. Ranjard et al. (2000) demonstrated

Received for publication 31 Jan. 2005. Accepted for publication 28 Apr. 2005.

${ }^{1}$ To whom reprints should be addressed; e-mail wrkussow@wisc.edu. influences that an active microbial community can have on plant health (Hodges, 1990). More recently, Feng et al. (2002) showed bacterial counts for sand-based putting greens to be on the order of $10^{9}$ cells/g of soil, which is in the magnitude of native bacterial community densities. However, the establishment and maintenance of root-zone microbial communities has been shown to relate to the age of the putting green (Aslan et al., 1999; Bigelow et al., 2002; Elliot et al., 2004). Bigelow et al. (2002), observed development of a large $\left(10^{8} \mathrm{cfu} / \mathrm{g}\right.$ of dry soil) and relatively stable microbial community over the 2 -year period following construction of a sand-based green. After construction, the putting green microbial communities undergo gradual shifts in composition and density (Elliot and Des Jardin, 2001; Elliot et al., 1999, 2004). Even though more data has been collected, there are many unanswered questions about how the microbial communities interact with established stands of creeping bentgrass.

The soil microbial community and higher plants have intricate relationships that are both mutually beneficial and competitive. Plant growth can be stimulated by rhizosphere microorganisms that are capable of producing plant growth regulators (Martens and Frankenberger, 1993; Timmusk et al., 1999). Pathogen damage to turfgrass can be reduced by disease suppressing microorganisms (Kageyama and Nelson, 2003; McKellar and Nelson, 2003; Nelson and Boehm, 2002; Nelson and Craft, 2000; Viji et al., 2003). However, in most instances the primary benefit of an active rhizosphere community to the plant community results from mineralization of organic substrates (Tate, 1995).

The turf industry has responded by marketing a wide array of biostimulants, which are loosely defined as turf amendments composed of natural wetting agents, seaweed extracts, plant hormones and microbial inoculums (Karnok, 2000). Some biostimulant products claim to increase soil microbial density and activity, which in turn enhances turfgrass quality due to increased organic matter decomposition and improved nutrient availability. These assumptions are based on previous research in other plant systems, which has shown that rhizosphere microbial activity can positively influence plant growth rates by increasing nutrient availability, inducing plant hormone-like compounds and reducing colonization of pathogens (Craft and Nelson, 1996; Groger, 1992; Hoflich et al., 1994; Paul and Clark, 1989). Chen et al. (2002) demonstrated increased dehydrogenase activity 1 week after the addition of two different agricultural amendments to soil microcosms, which indicates that the microbial community was stimulated by the addition of easily available carbon sources and other nutrients. Comparable studies have not been carried out in sand-based root-zone mixtures or in the putting green environments. The purpose of the present study was to determine how a select group of commercial biostimulants may alter the microbial community in a sand-matrix putting green and to link these changes to the quality of the creeping bentgrass playing surface.

\section{Materials and Methods}

Field experiment. The research site was a sand-based putting green constructed in 1996 at the University of Wisconsin O.J. Noer Turfgrass Research Station in Verona. The putting green was constructed according to USGA (1993) standards with a commercial 
root-zone mixture consisting of $80 \%$ sand: $20 \%$ sphagnum peat humus. Plastic sheeting $(6 \mathrm{~mm})$ was installed to the full depth of the root-zone mix to isolate the $1.8 \times 2.4 \mathrm{~m}$ plots in the putting green. 'SR 1119 ' creeping bentgrass [Agrostis stolonifera var. palustris (Huds.) Farw.] was grown-in during Spring 1997. The present study was initiated in Spring 2000, as the putting green was entering its third year after grow-in.

The five commercial biostimulants tested in this study were Flexx-Plus, Colonize T\&O (Plant Health Care, Inc., Pittsburgh, Pa.), Experimental Microbial Stimulant A (Expt. A), Experimental Microbial Stimulant B (Expt. B), and Raiz-Mor. Flexx-Plus (Plant Health Care, Inc.) contained yucca wetting agent, beneficial bacteria, sea kelp, humic and fulvic acids. Colonize T\&O was a combination of vesicular arbuscular mycorrhizae (VAM) fungi, bacteria $\left(10^{9} \mathrm{cfu} / 2.2 \mathrm{~kg}\right)$, humic acids, sea kelp, and carbon sources for bacteria. Exp A and B (Ocean Organics, Waldoboro, Mass.) contained seaweed extracts fortified with glucose. Raiz-Mor (Jay-Mar, Inc., Plover, Wis.) is sold as a surfactant-wetting agent containing seaweed and plant extracts. All treatments were analyzed for their mineral nutrient contents (Table 1) because biostimulants labeling is often incomplete for nutrient contents.

Four of the products, Flexx-Plus, Colonize T\&O, Expt. A and Expt. B were applied as solutions with $\mathrm{CO}$, backpack sprayer calibrated to deliver $571 \mathrm{~L} \cdot \mathrm{ha}^{-1}$. Per the manufacturer's recommendation, the Raiz-Mor was coated on granular fertilizer at the rate of $946 \mathrm{~mL}$ per $113.4 \mathrm{~kg}$ of fertilizer. Rates of application of the other products were Flexx-Plus at 38.3 $\mathrm{kg} \cdot \mathrm{ha}^{-1}$, Colonize $\mathrm{T} \& \mathrm{O}$ at $2.78 \mathrm{~kg} \cdot \mathrm{ha}^{-1}$, and Experimental A and B at $92.7 \mathrm{~mL} \cdot \mathrm{ha}^{-1}$. The biostimulants were applied biweekly from 29 May until 21 Aug. 2000. A complete fertilizer, IsoTek 18N-1.31P-13.3K (Lebanon Turf, Lebanon, Pa.), served as the control and was applied biweekly at the rate of $12 \mathrm{~kg} \cdot \mathrm{ha}^{-1}$ nitrogen to all plots following the same schedule as the biostimulants. The treatments were randomized in a complete block experimental design with four replications.

Routine maintenance was similar to that of golf courses in the area of Madison, Wisconsin. The bentgrass was mowed 6 times a week at a height of $4.0 \mathrm{~mm}$ and clippings removed. Pesticide applications (chlorothalonil and chlorpyrifos) were on a curative basis for dollar spot (Sclerotina homoecarpa) and black cutworm (Argoispiolon hufnagel). The putting green was groomed and lightly sand top-dressed on a monthly basis. The creeping bentgrass was irrigated daily at $100 \%$ of the estimated plant ET (Diak et al., 1998). The putting green was aerified once with $64 \mathrm{~mm}$ $(1 / 4-i n c h)$ diameter quadratines to a depth of $5.0 \mathrm{~cm}$ on $5 \times 5 \mathrm{~cm}$ spacings.

Soil samples were removed about every 2 weeks (22 May, 12 June, 28 June, 10 July, 24 July, 7 Aug., 21 Aug., 5 Sept., 18 Sept., and 2 Oct.) for a total of ten times by taking twelve randomly chosen cores of $1.25 \mathrm{~cm}$ in diameter to a $15.24-\mathrm{cm}$ depth. The soil cores were processed by first removing the mat layer (topdressing sand intermingled with thatch and stolons) and then homogenizing the soil sample (Elliot et al., 1998). The soil samples were stored at $4{ }^{\circ} \mathrm{C}$ until further processing and analysis.

Turfgrass quality was visually assessed biweekly by rating for color, grass uniformity, and abundance of localized dry spot (LDS). The standard rating scale of 1 to 9 (Skogley and Sawyer, 1992) was used. A rating of 6.0 was set as representing a minimally acceptable value from the perspective of putting green performance. A single person performed all quality measurements to ensure the highest level of consistency between the individual ratings. The three ratings, all considered to be elements of putting green quality, were combined into a single composite value for statistical purposes. Bentgrass clippings were collected three times during the growing season and analyzed for total essential nutrient content to check possible influences of the biostimulants on the nutritional status. Clippings were oven-dried at $70{ }^{\circ} \mathrm{C}$ for about $24 \mathrm{~h}$ and then analyzed for percent nitrogen content following the method of Bremner (1965). All other nutrients were measured by inductively coupled plasma optical emission spectrometry on samples digested according to the method of Huang and Schulte (1985) at University of Wisconsin-Madison Soil and Plant Analysis Laboratory.

Microbial activity and biochemical assessment. Microbial activity was assessed by measuring four extracellular soil enzymes: dehydrogenase, cellulase, invertase and xylanase. Dehydrogenase, an overall indicator of microbial activity (Dick, 1997) was measured by the colorimetric procedure wherein triphenyl tetrazolium chloride (TTC) is reduced to triphenyl formazan (TPF) $(\mathrm{Ca}-$ sida et al., 1964). Cellulase, invertase and xylanase activities were measured to assess microbial carbon cycling and biomass turnover within the root-zone using the methods developed by Schinner and von Mersi (1990). Soil enzyme activity was measured for all sampling dates.

Substrate utilization patterns were determined using Biolog Gram-negative plates (Biolog, Haywood, Calif.). The carbon substrate plates have been used to distin-

Table 1. Mineral analysis of the commercial biostimulant products.

\begin{tabular}{lcccc}
\hline & \multicolumn{4}{c}{ Element in biostimulant (\%) } \\
\cline { 2 - 5 } Products & Nitrogen & Phosphorus & Potassium & Iron \\
\hline Flexx-Plus & 0.08 & 0.20 & 8.84 & 4.81 \\
Colonize T\&O & 0.07 & 2.58 & 9.32 & 0.02 \\
Experimental A & 2.92 & 0.03 & 1.08 & 2.35 \\
Experimental B & 3.19 & 0.02 & 0.94 & 2.06 \\
Raiz-Mor & 1.51 & 0.13 & 0.02 & 0.001 \\
\hline
\end{tabular}

guish differences in microbial communities associated with different plant communities and arising from additions of various organic soil amendments (Burkett and Dick, 1998; Grayston et al., 1998). Substrate utilization profiles were assessed five times using soil samples collected on 22 May, 28 June, 24 July, 21 Aug., and 2 Oct. 2000. The soil samples collected 22 May before any biostimulant application provided background data for all comparisons. Briefly, $10 \mathrm{~g}$ (dry weight) of soil were added to $90 \mathrm{~mL}$ of sterile saline buffer and shaken for $1 \mathrm{~h}$ at $200 \mathrm{rpm}$. A 100$\mu \mathrm{L}$ sample from the $10^{-3}$ soil extract dilution was added to each well in the Biolog gramnegative microplates (Balser, 2000; Biolog, 1993; Zak et al., 1994). The microplates were incubated at $30^{\circ} \mathrm{C}$ in an airtight container with extra water to reduce plate evaporation. Color development of the Biolog plates was read four times at $12-\mathrm{h}$ intervals after the initial 4-h background reading. Plate readings from the 48-h time point were used for all analyses after noting that after this time there were no further positive reactions for any of the substrate. Readings were collected with a MRX Microplate Reader (Dynateck Laboratories, Inc., Borehamwood, U.K.) set at $590 \mathrm{~nm}$ to measure color development. Bio Linx: Assay Management software version 2.22 (Dynex Technologies, Inc., Chantilly, Va.) was used to evaluate the data.

Statistical analysis. Data analyses were performed using SAS Version 8 (SAS Institute Inc., Cary, N.C.). The data collected in the biweekly sampling schedules were consolidated into 10 cycles. All data except the substrate utilization profiles were analyzed with a repeated measurements procedure. Student's $t$ tests and least squared means (LSM) were used to compare the treatments, date, and the treatments by date interactions for significant differences. Substrate richness was calculated by determining the percentage of the 95 carbon substrates oxidized (Ellis et al., 1995). Applying the criteria of Burkett and Dick (1998), each well with absorbency over 0.5 was counted as a positive response. The number of positive responses at $48 \mathrm{~h}$ was divided by the number of carbon sources on the plates to determine the percent of carbon substrates used. The raw data from the BiologGram negative plates were used to calculate the average well color development (AWCD) for each plate (Garland and Mills, 1991). The 95 carbon substrates were then separated into 6 guilds: carbohydrates, carboxylic acids, polymers, amino acids, amines/amides, and miscellaneous based on a substrate evenness analysis developed by Zak et al. (1994). Using the carbon substrate guilds reduces the amount of information lost when a single value is derived from all 95 carbon substrates. The mean value of each guild was used in a MANOVA analysis. Substrate richness and carbon substrate guild data were evaluated by least square means with student $t$ test used to determine significance. Interactions between turfgrass visual quality and the microbial community indicators were evaluated by way of Pearson correlation coefficients. 


\section{Results}

Microbial activity and biochemical assessment. The activities of the four edaphic enzymes measured in this study were uniformly very low as compared to cropland soils. For example, the dehydrogenase and invertase levels measured were 100 to 200 times lower than those reported by Pickel and Hayes (1990) for soil collected from Indiana farms with corn-soybean rotations. One very plausible reason for this sharp contrast in levels of microbial activity is that the sand-based root zone material that was in this study was strongly substrate limiting. According to Tate (1995), restrictions in carbon resource are what most commonly controls soil microbial community development. Therefore, the application of a biostimulant with energy rich carbon would appear to have considerable potential for enhancing microbial activity for short periods of time.

The biostimulant treatments either never altered enzyme activity or did so only temporarily. When compared to the control (fertilizer only) treatment, significant changes in dehydrogenase activities $(p<0.01)$ were sporadic, occurring in the Flex-Plus treatment on 28 June and 24 July, 28 June for Colonize T\&O and Expt. A, and 10 July for Raiz-Mor (Fig. 1). Cellulase (Fig. 2), invertase, and xylanase activities (data not shown) were never significantly increased as a result of biostimulant application.

The most pronounced change in enzyme levels that was highly significant $(p=0.01)$ was the downward trend in cellulase activity as the growing season progressed (Fig. 2). This is indicative of a progressive decline in substrates originating from sources other than the organic compounds being applied.

Bacterial substrate utilization patterns were also used to detect changes in indigenous bacteria activity. A larger percent of positive wells for the treatments compared to the control was used to indicate increased metabolic capabilities of the bacterial community. The percent positive wells ranged between $45 \%$ to $54 \%$ for the control treatment and $37 \%$ to $54 \%$ for the biostimulants (Table 2). With just two exceptions for 25 observations, there were no repeated significant differences across dates between the percentage of positive wells in the biostimulant treated soils and the untreated control.

In an effort to more clearly identify any divergences in the microbial communities as a result of biostimulant application, the 95 Biolog carbon sources were divided into six different carbon guilds. Statistical analyses indicated that there were few significant changes in carbon guild utilization from the beginning to the end of the season (Table 3 ). The few significant treatment effects noted occurred sporadically across the five sampling dates and provided no hard evidence that the biostimulants induced sustained changes in the composition or metabolic activity of the microbial communities.

Turfgrass quality. While the biostimulants had no noteworthy influences on soil microbial activity or composition of the microbial community, in most cases they did improve the visual quality of the turfgrass (Table 4). The one exception was a decrease in turfgrass quality observed after an excessive rainfall event $(6.2 \mathrm{~cm})$ on 13 June 2000 . Increased turfgrass quality was sustained for $30 \mathrm{~d}$ after biostimulant and fertilizer application ended on 21 Aug. Ratings began to decline shortly after 12 Sept. Significant improvements in turfgrass quality were repeatedly measured for all biostimulant treatments across all sampling cycles. An interaction between the treatment effects and sampling cycles proved to be significant $(p<0.05)$, indicating that the treatment effects out-performed natural variation in the system.

All individual measurements of turfgrass quality (e.g., color, stand uniformity, and the occurrence of localized dry spot) were positively influenced by the biostimulants (Table 5). However, it was the percentage of plot area with

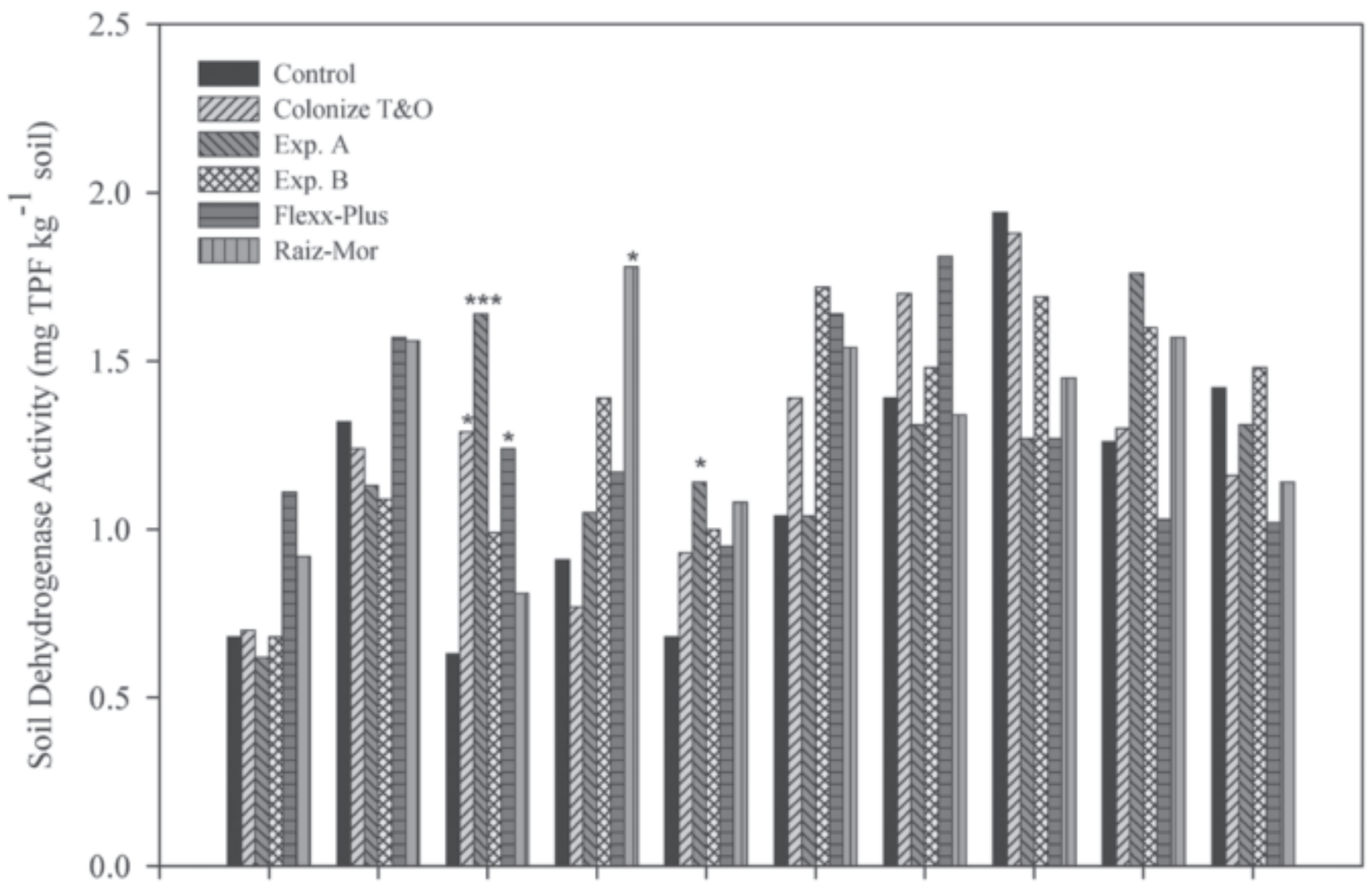

29 May 12 June 28 June 10 July 24 July 7 Aug. 21 Aug. 5 Sept. 18 Sept. 2 Oct.

\section{Sampling Date}

Fig. 1. Seasonal changes in soil dehydrogenase levels following the application of five different commercial biostimulants.,***** Significant at $p=0.10,0.05$, and 0.01 , respectively for each treatment as compared to the control. Each column is a mean of three replicate measurements. 


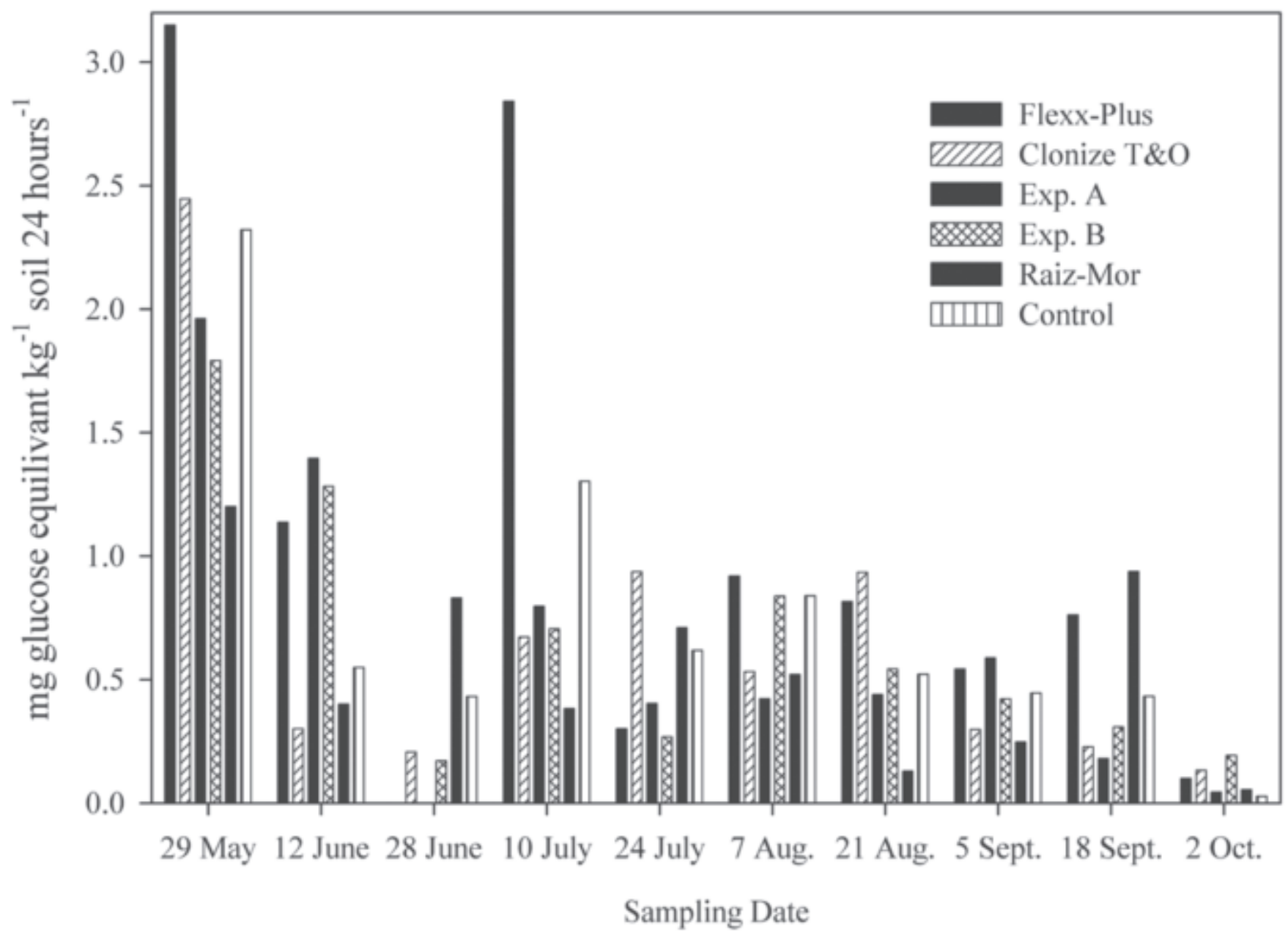

Fig. 2. Cellulase activity determined colorimetrically for the root-zone of a U.S. Golf Association style sand-based putting green over the 2000 field season following biweekly applications of commercial biostimulants and IsoTek $18 \mathrm{~N}-1.31 \mathrm{P}-13.3 \mathrm{~K}$ complete fertilizer.

Table 2. Substrate richness for bacterial communities determined by carbon utilization patterns and the percentage of positive reactions from Biolog Gram-negative plates for five soil sampling dates over the 2000 field season.

\begin{tabular}{lccccc}
\hline & \multicolumn{5}{c}{ Positive wells (\%) } \\
\cline { 2 - 6 } Treatment & 29 May & 28 June & 24 July & 21 Aug. & 2 Oct. \\
\cline { 2 - 6 } Flexx-Plus & 51.2 & 47.0 & 51.0 & 44.3 & 50.8 \\
Colonize T\&O & 48.2 & $52.3^{* *}$ & 50.5 & 46.1 & 53.2 \\
Experimental A & 50.3 & 41.1 & 54.7 & 47.7 & 52.2 \\
Experimental B & 48.5 & $52.9^{* * *}$ & 49.2 & 48.3 & 51.9 \\
Raiz-Mor & 48.9 & 37.1 & 53.7 & 46.0 & 51.4 \\
Control & 49.5 & 45.0 & 54.1 & 47.1 & 53.4 \\
\hline
\end{tabular}

*,****** Significant at $P \leq 0.05,0.01$, or 0.001 , respectively. Contrasts of biostimulant treatments against the control.

LDS that was most significantly decreased by the treatments. The treatments significantly reduced LDS $(p<0.05)$ for each observation date and the differences remained significant $(p<0.10)$ when seasonal trends were taken into account. These reductions in the extent of hydrophobic areas on the greens appear to provide the best explanation for biostimulant induced improvements in putting green quality.

Treatment effects on turfgrass plant nutrition did not explain improvements in turfgrass quality. Nutrient levels in the creeping bentgrass did not vary significantly over the season (Table 6). The levels of tissue nitrogen, zinc, manganese, and iron concentrations for 19 June were significantly increased compared with the control. However, this trend was not sustained for more of the nutrients (except Mn for Expt. B) in a subsequent sampling date. In the 18 Sept. tissue samples, $\mathrm{Ca}$ and $\mathrm{Mg}$ concentrations were higher than the control for all treatments. However, the other nutrient levels fell within sufficiency ranges for healthy turfgrass. Nitrogen availability may have played a role in intensifying color during the early part of the field experiment. Even with the biostimulants containing nitrogen at concentrations as high as $3 \%$ and potassium up to $9 \%$ in their formulations, the total quantities of nutrients applied via the biostimulants never exceeded $0.025 \mathrm{~kg} \cdot \mathrm{ha}^{-1}$.

The visual quality of the turfgrass was related to the microbial community measurements by way of a correlation matrix. There were no significant relationships between the application of biostimulants and the microbial community (data not shown).

\section{Discussion}

The commercial biostimulants tested in this field experiment significantly improved the visual quality of creeping bentgrass, but the treatments did not effectively alter the putting green microbial community in terms of enzyme activities and substrate utilization. In contrast, a study by Chen et al. (2002) revealed that commercial biostimulants possess the ability to increase microbial activity. In that study, the soil had been air-dried, sieved and stored for a year before use in microcosm experiments. Application of biostimulants would have provided an easily degradable source of organic matter for the dormant microorganisms and mostly likely explains the differences in dehydrogenase levels measured. In the present study, a mat layer (thatch and stolons intermingled with topdressing sand) was in place when the biostimulants were applied. The biostimulant carbon sources may not have migrated below this about 1.5 -cm-thick layer, which was removed before processing the soil cores. Mat layer removal limited the detection 


\begin{tabular}{|c|c|c|c|c|c|c|c|}
\hline \multirow[b]{3}{*}{ Date } & \multirow[b]{3}{*}{ Carbon guild } & \multicolumn{6}{|c|}{ Substrate evenness } \\
\hline & & \multicolumn{6}{|c|}{ Treatment } \\
\hline & & Flexx-Plus & Colonize T\&O & Experimental A & Experimental B & Raiz-Mor & Control \\
\hline 22 May & Carbohydrate & 0.700 & 0.585 & 0.599 & 0.666 & 0.673 & 0.665 \\
\hline 28 June & Carbohydrate & 0.567 & $0.721^{*}$ & $0.751^{* *}$ & $0.366^{* *}$ & $0.342^{* * *}$ & 0.559 \\
\hline 24 July & Carbohydrate & $0.670^{* * * *}$ & $0.718^{* *}$ & $0.627^{* * *}$ & 0.830 & 0.806 & 0.826 \\
\hline 21 Aug. & Carbohydrate & 0.531 & 0.521 & 0.527 & 0.541 & 0.561 & 0.578 \\
\hline 2 Oct. & Carbohydrate & $0.643^{* * * *}$ & $0.706^{* *}$ & $0.720^{*}$ & $0.689^{* *}$ & 0.732 & 0.792 \\
\hline 22 May & Carboxylic acids & 1.075 & 1.014 & 1.058 & $1.100^{*}$ & 1.070 & 0.981 \\
\hline 28 June & Carboxylic acids & 1.003 & $1.071^{* *}$ & $1.081^{* *}$ & $0.802^{* * *}$ & $0.705^{* * * *}$ & 0.942 \\
\hline 24 July & Carboxylic acids & $0.947^{* * *}$ & $0.933^{* * *}$ & $1.012^{* * *}$ & 1.147 & 1.103 & 1.148 \\
\hline 21 Aug. & Carboxylic acids & 1.010 & 0.980 & 1.011 & 1.078 & 1.024 & 1.040 \\
\hline 2 Oct. & Carboxylic acids & 1.018 & 1.062 & 1.042 & 1.055 & 1.056 & 1.069 \\
\hline 22 May & Polymers & 0.489 & 0.489 & $0.436^{*}$ & 0.493 & 0.576 & 0.516 \\
\hline 28 June & Polymers & 0.662 & $0.725^{* *}$ & $0.757^{* * * *}$ & 0.564 & 0.459 & 0.572 \\
\hline 24 July & Polymers & 0.593 & 0.538 & 0.521 & $0.775^{* * *}$ & 0.588 & 0.606 \\
\hline 21 Aug. & Polymers & 0.545 & 0.533 & 0.542 & 0.558 & 0.554 & 0.519 \\
\hline 2 Oct. & Polymers & 0.566 & 0.568 & 0.607 & 0.640 & 0.626 & 0.564 \\
\hline 22 May & Amines & 0.604 & 0.602 & 0.534 & 0.601 & 0.422 & 0.558 \\
\hline 28 June & Amines & $0.638^{* *}$ & $0.690^{* * *}$ & $0.814^{* * * *}$ & 0.498 & 0.409 & 0.456 \\
\hline 24 July & Amines & $0.454^{*}$ & $0.408^{* * *}$ & $0.412^{* * *}$ & 0.681 & 0.568 & 0.598 \\
\hline 21 Aug. & Amines & 0.391 & 0.402 & 0.483 & 0.430 & 0.404 & 0.414 \\
\hline 2 Oct. & Amines & 0.622 & 0.590 & 0.642 & 0.633 & $0.708^{* * *}$ & 0.472 \\
\hline 22 May & Amino acids & 1.154 & 0.980 & 1.035 & 1.156 & 1.003 & 1.140 \\
\hline 28 June & Amino acids & 1.255 & $1.357^{* * *}$ & $1.470^{* * * *}$ & 1.173 & $0.841^{\text {**** }}$ & 1.113 \\
\hline 24 July & Amino acids & $1.023^{* * * *}$ & $0.986^{* * *}$ & $0.941^{* * *}$ & $1.323^{* *}$ & 1.123 & 1.193 \\
\hline 21 Aug. & Amino acids & 0.820 & 0.959 & 0.910 & 1.016 & 0.978 & 0.912 \\
\hline 2 Oct. & Amino acids & 1.147 & 1.197 & 1.231 & 1.211 & 1.200 & 1.213 \\
\hline 22 May & Miscellaneous & $0.503^{* * * *}$ & $0.520^{* * * *}$ & $0.476^{* *}$ & $0.465^{* *}$ & $0.454^{* *}$ & 0.353 \\
\hline 28 June & Miscellaneous & $0.423^{* *}$ & $0.439^{* * *}$ & $0.555^{* * *}$ & 0.334 & 0.272 & 0.320 \\
\hline 24 July & Miscellaneous & 0.539 & 0.546 & 0.440 & $0.624^{* *}$ & 0.603 & 0.508 \\
\hline 21 Aug. & Miscellaneous & 0.380 & 0.477 & 0.452 & 0.624 & 0.406 & 0.435 \\
\hline 2 Oct. & Miscellaneous & 0.497 & 0.493 & $0.438^{* *}$ & 0.457 & 0.445 & 0.500 \\
\hline
\end{tabular}

${ }^{\mathrm{z}}$ Substrate evenness: $\mathrm{E}=\mathrm{H}^{\prime} / \mathrm{Hmax}, \mathrm{H}^{\prime}=-\Sigma$ pi (ln pi), Shannon index of diversity value; pi $=$ proportion of color development for $\mathrm{i}^{\text {th }}$ well.

${ }^{*, * * * * * * *}$ Significant at $P \leq 0.05,0.01$, or 0.001 , respectively as compared to control.

Table 4. Creeping bentgrass (Agrostis stolonifera L.) 'SR 1119' visual quality ratings (e.g., the composite of color, percentage of localized dry spot, and turfgrass uniformity) following repeated applications of five biostimulant treatments starting at 29 May and continuing until 21 Aug.

\begin{tabular}{|c|c|c|c|c|c|c|c|c|c|c|}
\hline \multirow[b]{3}{*}{ Treatment } & \multicolumn{10}{|c|}{ Quality rating } \\
\hline & \multicolumn{10}{|c|}{ Observation day } \\
\hline & 29 May & 5 June & 19 June & 10 July & 24 July & $1 \mathrm{Aug}$ & 16 Aug. & 29 Aug. & 12 Sept. & 2 Oct. \\
\hline Flexx-Plus & 7.2 & $7.3^{* * * *}$ & $6.4^{* * * *}$ & $7.1^{* *}$ & $7.6^{* * * *}$ & $8.0^{* * *}$ & 7.4 & 7.9 & 7.9 & 7.2 \\
\hline Colonize T\&O & 6.5 & 6.4 & 5.1 & $7.2^{* *}$ & $7.5^{* *}$ & $7.8^{*}$ & 7.6 & 7.8 & 7.8 & 6.8 \\
\hline Experimental A & 6.8 & $7.1^{* *}$ & $6.5^{* * *}$ & $7.4^{* * * *}$ & $7.5^{* * * *}$ & $7.9^{* *}$ & 7.7 & 7.9 & 7.9 & 7.0 \\
\hline Experimental B & 7.2 & $7.1^{* *}$ & $6.7^{* * * *}$ & $7.5^{* * * *}$ & $7.5^{\text {**** }}$ & $8.0^{* *}$ & 7.3 & 8.0 & 7.9 & 7.3 \\
\hline Raiz-Mor & 7.3 & 6.9 & $6.4^{* * * *}$ & $7.6^{\text {***** }}$ & $7.7^{* * * *}$ & $8.0^{* *}$ & $7.8^{* * *}$ & 8.0 & 8.0 & 7.2 \\
\hline Control & 6.2 & 6.4 & 5.1 & 6.6 & 6.7 & 7.3 & 7.5 & 7.7 & 7.6 & 6.8 \\
\hline
\end{tabular}

${ }^{*, * * * * * * *}$ Contrasts of biostimulant treatments against the control significant at $P \leq 0.05,0.01$, or 0.001 , respectively.

Table 5. Visual localized dry spot ratings for creeping bentgrass (Agrostis stlonifera L.) 'SR 1119' after repeated biweekly applications of the five biostimulant treatments applied at manufacturers rates starting at 29 May and continuing until 21 Aug.

\begin{tabular}{|c|c|c|c|c|c|c|c|c|c|c|}
\hline \multirow[b]{3}{*}{ Treatment } & \multicolumn{10}{|c|}{ LDS rating $^{\mathrm{a}}$} \\
\hline & \multicolumn{10}{|c|}{ Observation day } \\
\hline & 29 May & 5 June & 19 June & 10 July & 24 July & 1 Aug & 16 Aug. & 29 Aug. & 12 Sept. & 2 Oct. \\
\hline Flexx-Plus & $7.6^{* * * *}$ & 8.0 & $7.4^{* *}$ & 7.4 & $7.9^{*}$ & 7.8 & 7.5 & 8.5 & 8.5 & 7.9 \\
\hline Colonize T\&O & 5.9 & 7.3 & 5.5 & $7.9^{*}$ & $8.1^{* *}$ & 8.1 & 8.2 & 8.2 & 8.4 & 7.7 \\
\hline Experimental A & $6.5^{\text {*** }}$ & 8.3 & $7.5^{* *}$ & $8.0^{*}$ & $8.0^{*}$ & 8.1 & 8.1 & 8.4 & 8.5 & 7.9 \\
\hline Experimental B & $7.5^{* * * *}$ & $8.4^{*}$ & $7.9^{* * * *}$ & $8.0^{*}$ & $8.5^{* * *}$ & 8.4 & 7.5 & 8.5 & 8.4 & 7.9 \\
\hline Raiz-Mor & $7.8^{* * * *}$ & $8.6^{* * *}$ & $7.4^{* * *}$ & $8.4^{* * *}$ & $8.6^{* * * *}$ & 8.3 & 8.3 & 8.5 & 8.8 & 8.0 \\
\hline Control & 5.1 & 7.4 & 6.1 & 7.0 & 6.9 & 7.5 & 7.9 & 8.0 & 8.0 & 7.3 \\
\hline
\end{tabular}

${ }^{\mathrm{z}}$ LDS Rating based on a scale of 1 to 9 , with $9=$ a green without any areas of LDS.

${ }^{*, * * * * * * *}$ Contrasts of biostimulant treatments against the control significant at $P \leq 0.05,0.01$, or 0.001 , respectively.

of more pronounced biostimulant influences on microbial activity. In a turfgrass setting, Feng et al. (2002) demonstrated that the plant growth regulator, trinexapac-ethyl, did not alter the turfgrass microbial community. These results suggest permanent plant cover limits the benefits of foliar applied products upon soil microbial communities. Additionally, Sigler et al. (2001) successively added Pseudomonas aureofaciens TX-1 to creeping bentgrass; this did not change community composition as detected by a molecular analysis. Foliar applications of large bacterial densities do not change the indigenous soil microbial community, and suggesting that products containing beneficial bacteria in the formulation would not have altered community structure.

Substrate utilization patterns gave no indi- cation that significant shifts in the putting green microbial communities were triggered by the biostimulants. Instead, the results indicate possible spatial differences within the putting green environment because of how the percentage of carbon substrate utilization varied slightly but insignificantly between treatments. Only fast growing bacteria are known to respond quickly to the high nutrient levels in Biolog 
Table 6. Plant essential nutrients in creeping bentgrass (Agrostis stolonifera L.) leaf tissue from the 2000 season.

\begin{tabular}{|c|c|c|c|c|c|c|c|c|c|c|c|c|}
\hline \multirow[b]{2}{*}{ Date } & \multirow[b]{2}{*}{ Treatment } & \multirow{2}{*}{$\begin{array}{c}\mathrm{N} \\
\left(\mathrm{mg} \cdot \mathrm{kg}^{-1}\right)\end{array}$} & $\mathrm{P}$ & $\mathrm{K}$ & $\mathrm{Ca}$ & $\mathrm{Mg}$ & $\mathrm{S}$ & $\mathrm{Zn}$ & B & $\mathrm{Mn}$ & $\mathrm{Fe}$ & $\mathrm{Cu}$ \\
\hline & & & \multicolumn{5}{|c|}{$\left(\mathrm{g} \cdot \mathrm{kg}^{-1}\right)$} & \multicolumn{5}{|c|}{$\left(\mathrm{mg} \cdot \mathrm{kg}^{-1}\right)$} \\
\hline 19 June & Flexx-Plus & 4.35 & 3.08 & --- & 4.13 & 2.89 & 3.73 & 40.7 & 6.55 & 42.3 & 237 & 20.1 \\
\hline 19 June & Colonize T\&O & 4.31 & 3.08 & --- & 4.11 & 2.86 & 3.59 & 39.2 & 6.12 & 43.9 & 297 & 22.0 \\
\hline 19 June & Experimental A & 4.44 & 3.11 & --- & 4.02 & 2.78 & 3.72 & 43.6 & 6.75 & 44.9 & 287 & 22.9 \\
\hline 19 June & Experimental B & 4.45 & 3.03 & --- & 4.07 & 2.83 & 3.76 & 43.5 & 7.62 & 49.5 & 280 & 20.0 \\
\hline 19 June & Raiz-Mor & 4.38 & 3.15 & --- & 4.13 & 3.00 & 3.89 & 42.2 & 7.15 & 41.4 & 241 & 20.2 \\
\hline 19 June & Control & 4.14 & 3.11 & --- & 3.97 & 2.85 & 3.56 & 46.8 & 6.40 & 44.7 & 532 & 32.5 \\
\hline LSD & & 0.05 & NS & --- & NS & NS & NS & 0.05 & NS & 0.05 & 0.05 & NS \\
\hline 14 Aug. & Experimental A & 4.14 & 4.82 & 18.8 & 3.91 & 3.20 & 4.22 & 43.0 & 6.02 & 26.5 & 256 & 22.5 \\
\hline 14 Aug. & Experimental B & 4.11 & 4.57 & 18.1 & 3.81 & 3.09 & 4.07 & 41.3 & 5.36 & 27.7 & 473 & 20.2 \\
\hline 14 Aug. & Colonize T\&O & 4.14 & 4.61 & 18.4 & 3.82 & 3.11 & 4.13 & 39.5 & 5.62 & 30.1 & 419 & 20.6 \\
\hline 14 Aug. & Flexx-Plus & 4.09 & 4.51 & 18.1 & 3.83 & 3.10 & 4.09 & 39.9 & 4.98 & 26.2 & 352 & 19.8 \\
\hline 14 Aug. & Raiz-Mor & 4.31 & 4.83 & --- & 3.87 & 3.14 & 4.35 & 41.4 & 5.09 & 24.8 & 230 & 21.2 \\
\hline 14 Aug. & Control & 4.27 & 4.44 & 17.6 & 3.57 & 2.93 & 3.98 & 38.7 & 5.14 & 29.6 & 551 & 21.1 \\
\hline LSD & & NS & NS & NS & NS & NS & NS & NS & NS & 0.05 & NS & NS \\
\hline 18 Sept. & Experimental A & 3.70 & 4.21 & 17.6 & 4.29 & 3.01 & 3.41 & 37.1 & 4.65 & 25.1 & 285 & 17.6 \\
\hline 18 Sept. & Experimental B & 3.60 & 4.03 & 17.1 & 4.40 & 3.08 & 3.35 & 36.8 & 4.82 & 26.4 & 327 & 17.0 \\
\hline 18 Sept. & Colonize T\&O & 3.55 & 4.14 & 17.6 & 4.22 & 3.02 & 3.41 & 35.8 & 5.49 & 28.4 & 361 & 17.6 \\
\hline 18 Sept. & Flexx-Plus & 3.43 & 3.92 & 16.8 & 4.23 & 2.95 & 3.24 & 36.5 & 4.00 & 25.7 & 345 & 16.7 \\
\hline 18 Sept. & Raiz-Mor & 3.71 & 4.33 & 17.7 & 4.40 & 3.05 & 3.48 & 38.2 & 4.25 & 23.9 & 248 & 17.5 \\
\hline 18 Sept. & Control & 3.51 & 4.19 & 17.6 & 4.06 & 2.93 & 3.46 & 36.5 & 5.79 & 28.1 & 366 & 18.0 \\
\hline LSD & & NS & NS & NS & 0.05 & 0.05 & NS & NS & 0.05 & NS & NS & NS \\
\hline
\end{tabular}

NSNonsignificant.

wells (Degens et al., 2000; Garland and Mills, 1991), which suggests only a small percentage of the populations were measured using this technique. However, if one assumes that the primary carbon resources in this study were root exudates, this may not be true by virtue of the fact that root exudates stimulate primarily fast growing microbes (Tate, 1995). The differences observed between the treatments and control did not suggest an altered population of fast growing bacteria in the root-zone. The results also indicated that the carbon compounds contained in the commercial products were easily degradable and could be utilized by the indigenous community without acquiring new metabolic capabilities.

Response of the creeping bentgrass to the biostimulants was judged not to be nutritional in origin because the nutrient concentrations in the bentgrass leaf tissue were not altered significantly. Furthermore, all nutrient levels fell within the sufficiency ranges for healthy creeping bentgrass (McCarty, 2001). The most plausible explanation for increased turfgrass quality in our study are that different components in the biostimulants reduced localized dry spot and, in turn, may have increased the heat and moisture stress tolerance of the creeping bentgrass stand. Decreases in the incidence of localized dry spot have been achieved with commercial surfactants, the result being higher creeping bentgrass quality during summer heat stress (Kostka, 2000). Zhang et al. (2003) showed that both humic acids and seaweed extracts can improve turfgrass quality during July, an early part of summer decline. In this study, two of the biostimulant products contained wetting agents and the other three products contained some type of seaweed extract or humic acid, which most likely explains any increases in turfgrass quality.

Perhaps the most important observation from this field study was the decreases in soil enzyme activity as the season progressed. This trend suggests that in the 3 -year-old putting green studied, microbial community activity was governed by something other than the physical soil environment or the products applied to the system. Creeping bentgrass responds negatively to high ambient air and soil temperatures (Huang and Gao, 2000; Huang and $\mathrm{Xu}, 2003$; Liu and Huang, 2000). When creeping bentgrass is under heat stress, net photosynthate production declines and fixed carbon is preferentially partitioned to stems and shoots rather than roots (Xu and Huang, 2001). Huang and Xu (2003) demonstrated that the total amount of carbon in the root systems decreases during the hotter months (May to August) and then increases when temperatures decline. Soil temperatures in our putting green over July to August ranged from 22 to $26{ }^{\circ} \mathrm{C}$, which are above the optimum temperature for creeping bentgrass. Bokhari and Singh (1974) have demonstrated that temperature suppression of grass growth is accompanied by reductions in total root exudate production, not because exudate production per unit of root changes, but because of root mortality. This supports the suggestion of Bigelow et al. (2002), that reductions in substrate availability decrease total microbial numbers in sand-based turfgrass stands. Additionally, Feng et al. (2002) presented evidence that root die back was responsible for lower total bacteria in cool season turfgrass than in a warm season turf stand. Indeed, Farrar et al. (2003) have expressed the view that amounts of exudates released by plant roots are a controlling factor in the activity of soil microbial communities.

Declining quantities of root exudates associated with heat stress are clearly a plausible explanation for the decreases in microbial activity observed over time in this study. This implies is that the carbon substrates applied via the biostimulants were inconsequential with regard to alteration of root zone microbial activity. Rather, our observations suggest that it was reductions in LDS that increased turfgrass visual quality.

\section{Literature Cited}

Aslan, M.R., A. Drijber, W.L. Powers, R.C. Shearman, R.E. Gaussin, and A.M. Streich. 1999. Accumulation of microbial biomass within particulate organic matter of aging golf course greens. J. Paper 12775.

Balser, T.C. 2000. Linking microbial communities and ecosystem functioning. PhD diss. Univ. Calif., Berkeley.

Bigelow, C.A., D.C. Bowman, and A.G. Wollem, II. 2002. Characterization of soil microbial population dynamics in newly constructed sand-based root zones. Crop Sci. 42:1611-1614.

Biolog, I., 1993. GN MicroPlate Instructions for Use, Biolog, Inc., Hayward, Ca.

Bokhari, U.G. and J.S. Singh. 1974. Effects of temperature and clipping on growth, carbohydrate reserves, and root exudation of western wheatgrass in hydroponic culture. Crop Sci. 14:790-794.

Bremner, J.M. 1965. Total nitrogen, p. 1149-1176. In: C.A. Black, D.D. Evans, J.L. White, L.E. Ensminger, and F.E. Clark (eds.). Methods of soil analysis. Part 2. Amer.Soc. Agron., Madison.

Burkett, J.Z. and R.P. Dick. 1998. Microbial and soil parameters in relations to $\mathrm{N}$ mineralization in soils of diverse genesis under differing management systems. Biol. Fert. Soils. 27:430-438.

Casida, Jr., L.E., D.A. Klein, and T. Santoro. 1964. Soil dehydrogenase activity. Soil Sci. 98:371-376.

Chen, S., S. Subler, and C.A. Edwards. 2002. Effects of agricultural biostimulants on soil microbial activity and nitrogen dynamics. Appl. Soil Ecol. 19:249-259.

Craft, C.M. and E.B. Nelson. 1996. Microbial properties of composts that suppress dampingoff and root rot of creeping bentgrass caused by Pythium graminicola. Appl. Environ. Microbiol. 62:1550-1557.

Degens, B.P., L.A. Schipper, and M. Vojvodic-Vukovic. 2000. Decreases in organic $C$ reserves in soils can reduce the catabolic diversity of soil microbial communities. Soil Biol. Biochem. 32:189-196.

Diak, G.R., M.C. Anderson, W.L. Bland, J.M. Norman, J.M. Mecikalski, and R.M. Aune. 1998. Agricultural management decision aids driven by real time satellite data. Bul. Amer. Meteorol. Soc. 79:1345-1355. 
Dick, R.P. 1997. Soil enzyme activity as integrative indicators of soil health, p. 121-156. In: C. Pankherst, B.M. Doube, and V.V.S.R. Gupta (eds.). Biological indicators of soil health. CAB Intl., Wallingford, U.K.

Elliot, M.L. and E.A. Des Jardin. 2001. Fumigation effects on bacterial populations in new golf course bermuda grass putting green. Soil Biol. Biochem. 33:1841-1849.

Elliot, M.L., E.A. Guertal, and H.D. Skipper. 2004. Rhizosphere bacterial population flux in golf course putting greens in the southeastern United States. HortScience 39:1754-1758.

Elliot, M., H. Skipper, and E. Guertal. 1998. Bacterial populations and diversity within new USGA putting greens, p. 10-12. USGA, Far Hills, N.J.

Elliot, M.L., H. Skipper, and B. Guertal. 1999. Bacterial population and diversity within new USGA putting greens. 1999 Turfgrass Enviro. Res. Sum. USGA Green Sect., Far Hills, N.J.

Ellis, R.J., I.P. Thompson, and M.J. Bailey. 1995. Metabolic profiling as a means of characterizing plant-associated microbial communities. FEMS Microbiol. Ecol. 16:9-18.

Farrar, J., M. Hawes, D. Jones, and S. Lindow. 2003. How roots control the flux of carbon to the rhizosphere. Ecology 84:827-837.

Feng, Y.D., M. Stoeckel, E. van Santen, and R.H. Walker. 2002. Effects of subsurface aeration and triexapac-ethyl application on soil microbial communities in a creeping bentgrass putting green. Biol. Fert. Soils. 36:456-460.

Garland, J.L. and A.L. Mills. 1991. Classification and characterization of heterotrophic microbial communities on the basis of patterns of community-level sole-carbon-source utlizations. Appl. Environ. Microbiol. 57:2351-2359.

Grayston, S.J., S. Wang, C.D. Campbell, and A.C. Edwards. 1998. Selective influence of plant species on microbial diversity in the rhizosphere. Soil Biol. Biochem. 30:369-378.

Groger, H. 1992. Biologically active microbial compounds as useful agents in agriculture. World J. Microbiol. Biotechnol. 8:111-114.

Hodges, C.F. 1990. The microbiology of non-pathogens and minor root pathogens in high sand content greens. Golf Course Mgt. 48:60-75.

Hoflich, G., W. Wiehe, and G. Kuhn. 1994. Plant growth stimulated by inoculation with symbiotic and associative rhizoshpere microorganisms. Experientia 50:897-905.

Huang, B. and H. Gao. 2000. Growth and carbohy- drate metabolism of creeping bentgrass cultivars in response to increasing temperatures. Crop Sci. 40:1115-1120.

Huang, B. and Q. Xu. 2003. Seasonal changes in carbohydrate accumulation for two creeping bentgrass cultivars. Crop Sci. 43:266-271.

Huang, C.L. and E.E. Schulte. 1985. Digestion of plant tissue of analysis by ICP emission spectroscopy. Commun. Soil Sci. Plant Anal. 16:943-958

Kageyama, K. and E.B. Nelson. 2003. Differential inactivation of seed exudate stimulation of Pythium ultimum sporangium germination by Enterobacter cloacae influences biological control efficacy on different plant species. Appl. Environ. Microbiol. 69:1114-1120.

Karnok, K.J. 2000. Promises, promises: can biostimulants deliver? Golf Course Mgt. 68:67-71.

Kostka, S.J. 2000. Amelioration of water repellency in highly managed soils and the enhancement of turfgrass performance through the systematic application of surfactants. J. Hydrol. 231-232:359-368.

Liu, X. and B. Huang. 2000. Heat stress injury in relation to membrane lipid peroxidation in creeping bentgrass. Crop Sci. 40:503-510.

Mancino, C.F., M. Barakat, and A. Maricic. 1993. Soil and thatch populations in an $80 \%$ sand: $20 \%$ peat creeping putting green. HortScience 28:189-191.

Martens, D.A. and W.T. Frankenberger. 1993. Stability of microbial-produced auxins derived from L-tryptophan added to soil. Soil Sci. 155:263-271.

McCarty, L.B. 2001. Best golf course management practices. Prentice-Hall, Upper Saddle River, N.J.

McCoy, E.L. 1992. Quantitative physical assessment of organic materials used in sports turf root zone mixes. Agron. J. 84:375-381.

McKellar, M.E. and E.B. Nelson. 2003. Compostinduced suppression of Pythium damping-off is mediated by fatty-acid-metabolizing seed-colonizing microbial communities. Appl. Environ. Microbiol. 69:452-460.

Nelson, E.B. and M.J. Boehm. 2002. Compostinduced suppression of turf grass diseases. Biocycle 43:51-55.

Nelson, E.B. and C.M. Craft. 2000. Microbial strategies for the biological control of turfgrass diseases, p. 342-352. Fate and management of turfgrass chemicals.
Nunan, N.K., J. Wu, I.M. Young, J.W. Crawford, and K. Ritz. 2003. Spatial distribution of bacterial communities and their relationships with the micro-architecture of soil. Fems Microbiol Ecol. 44:203-215.

Paul, E.A. and F.E. Clark. 1989. Soil microbiology and biochemistry. Academic Press, Inc. San Diego.

Pickel, J.R. and J.M. Hayes. 1990. Influences of flyash on soil microbial activity and populations. J. Environ. Qual. 19:593-597.

Ranjard, L., F. Poly, J. Combrisson, A. Richaume, F. Gourbiere, J. Thioulouse, and S. Nazaret. 2000. Heterogeneous cell density and genetic structure of bacterial pools associated with various soil microenvironments as determined by enumeration and DNA fingerprinting approach (RISA). Microbial. Ecol. 39:263-272.

Schinner, F. and W. von Mersi. 1990. Xylanase-, CM-cellulase-, and invertase activity in soil: an improved method. Soil Biol. Biochem. 22: 511-515.

Skogley, C.R. and C.D. Sawyer. 1992. Field Research. In: D.V. Waddington, R.N. Carrow, and R.C. Shearman (eds.). Amer. Soc. Agron. Monogr. 32.

Tate, R.L. 1995. Soil microbiology. Wiley, New York.

Timmusk, S., B.M. Nicander, U. Grnahall, and E. Tillberg. 1999. Cytokinin production by Paenibacillus polymyxa. Soil Biol. Biochem. 31:1847-1852.

U.S. Golf Association. 1993. USGA recommendations for putting green construction. Green Sect. Rec. 31:2-21.

Viji, G., W. Uddin, and C.P. Romaine. 2003. Suppression of gray leaf spot (blast) of perennia ryegrass turf by Pseudomonas aeruginosa from spent mushroom substrate. Biol. Cont. 26:233-243.

$\mathrm{Xu}$, Q. and B. Huang. 2001. Morphological and physiological characteristics associated with heat tolerance in creeping bentgrass. Crop Sci. 41:127-133.

Zak, J.C., M.R. Willig, D.L. Moorhead, and H.G. Wildman. 1994. Functional diversity of microbial communities: Aquantitative approach. Soil Biol. Biochem. 26:1101-1108.

Zhang, X.Z., E.H. Ervin, and R.E. Schmidt. 2003. Plant growth regulators can enhance the recovery of kentucky bluegrass sod from heat injury. Crop Sci. 43:952-956. 